\title{
Using Multimedia Campaign Approach to Improve Farmer Knowledge on Soybean Production: A Case of Selected States in Nigeria
}

\author{
Richard Musebe $^{1 *} \quad$ James Watiti $^{1} \quad$ Solomon Duah $^{2}$ Innocent Okuku ${ }^{3}$ \\ 1.CABI, P.O. Box 633-00621, Nairobi, Kenya \\ 2.CABI, P. O. Box CT 8630 Cantonments, Accra, Ghana \\ 3.Intrio Synergy Limited, S01, Pathfield Mall, Gwarimpa, Abuja, Nigeria \\ *E-mail of the corresponding author: r.musebe@cabi.org
}

\begin{abstract}
Soybean is an important crop for human and animal consumption as well as industrial uses. It is a cheap plant food source that the low-income population in Nigeria depends on for protein and nutrient needs. However, there has been a decline in its production and productivity. To facilitate the transition to improved soybean productivity, multimedia campaigns were conducted to increase awareness of good agronomic practices and integrated soil fertility management approaches. The campaign used three elements; radio, print and video materials, to reach farmers in a complementary manner. This paper examines the implementation and effectiveness of the campaigns that were conducted in five (5) states in Nigeria in order to provide direction for future campaign endeavours in terms of participation by different stakeholders and how to fast track expected benefits to the farmers. This study established that the main source of information was the agricultural extension agents through face-to-face interactions, distribution of print materials and showing videos. Radio messages in local languages contributed to further increase in awareness. Farmers preferred to receive information from many sources and formats as it was perceived to reinforce learning. Model results asserted similarly that farmers' exposure to and understanding of messages was increased by the use of multimedia. The multimedia messages had a positive contribution to productivity and diversity in the practices taken up. Messages on use of inoculant were the most extensively used and farmers aver that they contributed to increases in productivity. The extent of use of messages was influenced by expected benefits, clarity and ease of access to inputs. To improve utilization and effectiveness of production messages, they should be accompanied with information on how to access agricultural finance and inputs plus how to market the soybeans.
\end{abstract}

Keywords: multimedia, knowledge, productivity, practices, inoculant, soybean

DOI: $10.7176 / \mathrm{JESD} / 10-24-01$

Publication date: December $31^{\text {st }} 2019$

\subsection{Introduction}

The current demand for soybean in Nigeria, for both human and animal consumption as well as industrial purposes, is estimated at over 2.1 million tonnes annually (Sahel, 2017). Although the country possesses both human and land resources to produce enough to meet its demand, it produces about 0.6 million tonnes leaving an annual gap of 1.5 million tonnes to be met through import (Ugbabe, 2017). At the same time, the country faces high youth unemployment, a weak national economy and currency that are significantly compounded by the huge annual import bills, and insecurity which has been strongly linked to the level of unemployment and poverty (Asaju, and Anyio. 2014).

Consequently, there is a focus on agriculture as a priority with the objective of becoming self-sufficient in production of key crops including soybean thereby creating jobs and strengthening the economy (Ado et. al., 2016, Olomola, 2007). Additionally, the market for soybean in Nigeria is growing very fast with opportunities for improving the income of farmers (Dugje et. al., 2009). Government policies to increase food production, including soybean production and to boost agricultural output for industrial and domestic utilization in Nigeria are in place (Agada, 2015). These include support for food security, import restrictions or an outright ban on some commodities including vegetable oil, fish and poultry products (RMRDC, 2004). The Anchor Borrowers Program (ABP), a government initiative led by the Central Bank of Nigeria (CBN) initiated in 2016, is another effort aimed at organizing farmers into groups to access production credit and linking them to markets thereby facilitating their transition from subsistence to commercial farming.

As part of its support for soybean, the International Institute of Tropical Agriculture (IITA) has been implementing a Bill and Melinda Gates Foundation (BMGF)-funded project called N2Africa since 2013 with the aim of increasing production and commercialization of soybean and other grain legumes. The project deals with empirical soybean production challenges, which include poor yielding varieties, inadequate information about new production technology, limited application of fertilizers and limited utilization of rhizobia inoculants in soils with no history of soybean production (Woomer et. al., 2012; Agada, 2015, Sahel, 2017, Girei et. al. 2018). From its 
inception to 2016, the N2Africa project has only reached an estimated 90,000 smallholder soybean farmers in Nigeria with education on good agricultural practices (GAP) and integrated soil fertility management (ISFM) including inoculation, improved varieties and appropriate inputs. Most of the farmers reached are yet to achieve significant commercial benefits from the education. Besides, this reach is minimal compared to a potential farming population. There is need to improve promotion and dissemination of improved soybean technologies such as seeds, fertilizers and inoculants.

To facilitate the transition to improved soybean productivity, CABI's Africa Soil Health Consortium project (ASHC2) conducted scale-up campaigns aimed at increasing awareness of good agricultural practices and integrated soil fertility management approaches. The campaigns align with the assertion that, with careful soil fertility management and increased farmers' knowledge and experience, gross margins greater than US\$285.71 per hectare are feasible (Shehu et. al. 2007). The integrated campaigns were focused primarily on the beneficiaries of the N2Africa project, to support their access to information that would enable their adoption of the ISFM and GAP they have learnt while facilitating their linkage to credit and markets taking advantage of the ABP initiative. Ifeanyi et. al. (2007) acknowledges that, taking the appropriateness of the innovation as given, access to information about an innovation is the key determinant of farmers' adoption decisions. The campaigns were to help in the transition to commercial farming which would lead to improved income and wellbeing for the farmers while contributing to Nigeria's self-sufficiency in soybean production.

The campaign used three elements; radio, print and video materials, to reach farmers in a complementary manner. Selection of the media is in line with a study conducted in Ghana, where Ragsdale et. al. (2017) point out that strategies such as SMS, radio, video, and face-to-face plot demonstrations can be effective in disseminating critical soybean production and technology adoption information. The print materials included a GAP flipchart and a how-to-inoculate-with-NoduMax poster for use by extension workers in interpersonal engagement of farmers. The video materials included both a full-length GAP video for screening in viewing centres in rural communities and a set of light format short videos for sharing via mobile networks and social media platforms. The radio included promotional jingles for NoduMax and four (4) episodes of 30-minute discussion sessions each focusing on specific stages of the crop cycle to support farmers with advice on good practices.

This paper examines the implementation and effectiveness of the campaigns that were conducted in Nigeria in order to provide direction for future campaign endeavours in terms of participation by different stakeholders and how to fast track expected benefits to the farmers. The specific objectives were to: (i) assess farmer exposure to and understanding of campaign messages through different channels, (ii) examine the utilization of the campaign messages by the farmers, (iii) identify challenges to the use of information from the campaign messages and (iv) document key lessons learnt for future campaigns

\subsection{Materials and methods}

The campaigns were conducted in five (5) soybean-producing states; namely Benue, Kwara, Niger, Kaduna and Borno, which are also the major soybean producing states in Nigeria (Omotayo et. al. 2007b). Data for the study was collected from soybean farmers, extension workers and agro-dealers. Lists of farmers engaged in soybean production were obtained from the extension workers. The number of farmers varied from state to state with the least being Kwara and the highest being Borno. Random sampling was used to select farmers proportionately in such a way that $70 \%$ of them were from the top half of producer communities/ local government areas (LGAs) and the remainder coming from the lower producing LGAs. The selection process ensured that states with high numbers of farmers had a high representation while those with low numbers had a lower representation. Based on the population of soybean farmers in each of the states, respondents were randomly selected to generate 250 as the sample size for the farmers. Data for the study was also obtained from extension workers and agro-dealers that were purposively selected to serve as key informants. The selection process was such that about $30 \%$ of all the extension officers involved in the information campaigns participated in the study. Ten agro-dealers were selected from each of the states involved in the study. Representatives from all radio stations used in the campaigns were interviewed using structured questionnaires. Table 1 provides a complete list of all respondents for the study.

Table 1: Sample size according to category of respondents in different states

\begin{tabular}{lcccccc}
\hline Category of respondents & Benue & Niger & Kwara & Kaduna & Borno & All states \\
\hline Farmers & 47 & 32 & 13 & 66 & 92 & 250 \\
Extension officers & 9 & 12 & 6 & 14 & 6 & 47 \\
Agro-dealers & 10 & 10 & 10 & 10 & 10 & 50 \\
Radio stations & 2 & 2 & 2 & 2 & 1 & 9 \\
Total no. of interviewees & 68 & 56 & 31 & 92 & 109 & 356 \\
\hline
\end{tabular}

Data for the study was collected using questionnaires and interview guides in January 2018. Descriptive statistics, logistic regression and thematic analyses were used to achieve the objectives of the study. 


\subsection{Results and Discussion}

\subsection{Types of information required/received by farmers}

Farmers require all information regarding soybean practices starting with access to inputs up to marketing of soybeans. Planting, weeding, pest and disease management, harvesting, storage and marketing were the specific information needs. In the farmers' view, information on how to access finance for farming, weed control and increasing yield were most critical. Increasing yield was considered especially with respect to how to access and use inoculants. These were followed by fertilizer use and crop spacing. Understandably, all practices must be supported by the requisite financial resources. The types of information required in order of importance included how to get finances for investment in farming, how to increase yield and weed control (Table 2). Given the wide range of information required by farmers a multi-pronged approach is warranted to facilitate access. Multi-media campaigns are a key link to facilitate access to information given their cross-cutting nature. Moreover, strength of farmers' learning capabilities is through farmer-farmer dissemination of information on knowledge and skills acquired (Agada, 2014). This is consistent with Egwu (2014) who contends that farmers should organize themselves into co-operative societies which would supply information to their members.

An array of information was received by farmers about the key issues related to production of soybeans. The key messages delivered included the use of inoculant to increase yield, the right fertilizer to use and the best methods of planting and good spacing. Table 2 shows the proportion of farmers reporting receipt of different types of information.

Table 2: Information required and information received by farmers

\begin{tabular}{lrrrrr}
\hline Types of information & $\mathbf{N}$ & Required (\%) & Received (\%) & Chi-Square & p value \\
\hline How to get finance to invest in farming & 199 & 56.2 & 8.1 & 81.28 & 0.00 \\
Good chemicals for weed control & 198 & 43.2 & 50.2 & 2.81 & 0.09 \\
How to increase yield using inoculant & 199 & 43.0 & 79.2 & 41.18 & 0.00 \\
The right fertilizers and how to use & 199 & 41.8 & 76.0 & 42.29 & 0.00 \\
Best methods and spacing & 199 & 38.2 & 67.0 & 19.85 & 0.00 \\
How to get good seeds to buy & 200 & 35.9 & 49.8 & 9.01 & 0.00 \\
How to access good markets & 199 & 31.5 & 18.1 & 12.68 & 0.00 \\
Which soybean varieties to plant & 200 & 27.1 & 48.9 & 18.39 & 0.00 \\
How to get sufficient land for soybeans & 199 & 19.2 & 16.1 & 0.15 & 0.70 \\
\hline
\end{tabular}

Note: $\quad 1$. Percentages are computed based on the entire sample size of 250

2. McNemar test is used to establish significant differences

3. $\mathrm{N}$ reported in the table is based on paired comparisons for the McNemar test

4. Chi-Square is continuity corrected

A McNemar test revealed that there were statistically significant differences between the types of information received and what was required, for all information disseminated except information on weed control and how to get sufficient land $(\mathrm{p}<0.01)$ as shown in Table 2 column 5. More farmers reported to have received information compared to those who reported information required. This demonstrated improved access to information which indicated a good drive to improving soybean production. This is in line with the interest of the farmers given that farmers would be eager for more information on best practices for growing soybean, such as optimal row spacing and optimal inoculant and/or fertilizer applications (Ragsdale, et. al., 2017). Indeed, agricultural information interacts with, and influences, agricultural activities in a variety of ways (LawalIro, et. al. 2014). Information on how to access finance for soybean production was limited although it was critical information for the farmers. Access to finance can help farmers to purchase inputs necessary for soybean production. Michael (2011) reported that higher productivity is constrained by high cost of seeds and scarcity of superphosphate fertilizers. This suggests that information on good agricultural practices and integrated soil fertility management should be accompanied by explicit information on how to access finances and markets. How to access input and output markets is of critical concern. This argument is in line with earlier research (Agada, 2015; Ugwu and Nwoke, 2011), which stresses that extension agents should provide soybean farmers marketing information, establish viable links between respondents and relevant stakeholders in order to improve access to inputs and modern technologies. Partnership with relevant institutions such as research institutes, private companies, meteorological services market information systems contribute to success in implementing advisory methods (David and Cofini, 2017). At the same time local and state governments should establish rural markets with good marketing infrastructure and good rural roads to enable farmers have high returns on soybean investment. This is corroborated by the findings of Ojiako (2010) that easing farmers' access to credits will encourage willing farmers to invest in farmlands and improved technology while adequate training workshops and field days would help to update them on the appropriate use of new technologies and build up their knowledge and experience. Information on marketing of soybean was not provided as adequately as required by the farmers. This points to the need for inclusion of more marketing information in soybean promotion campaigns. Mbah, et. al. (1992) contends that having knowledge on how to get markets to retail soybean can stimulate farmers to produce the soybeans. Market 
information, especially price, is very vital for farmers in their decision of timing the sales (Asogwa et. al. 2012). Further, Omotayo (2007a) argues that for the poor to benefit from the soya commodity chain a mechanism that guarantees direct access of the poor, creates more opportunity, greater access to the market and its benefits, greater choice or reliability within the market, and more possibilities for mitigating risk through the market would need to be instituted.

\subsection{Sources of information, preferred sources of information and exposure to multimedia}

Farmers reported access to information from different sources (Table 3). The main source of information was the extension workers. Parents and guardians had significant contributions in terms of providing information on agricultural production. Other sources of information were friends and printed materials. The preferred sources of information in order of importance were extension officers followed by printed materials and radio (Table 3). A study by Opara (2008) revealed that $88.1 \%$ of the farmers' source of agricultural information was through extension agents. Similarly, Ozowa (2008) showed that among all the existing channels of communication, Nigerian farmers ranked extension workers the highest in providing credible information and advice. Ifeanyi et. al. (2007) established that farmers' adoption decisions were significantly influenced, by among other things, exposure to extension services. Celine and Tsue (2013) argue that inadequate/poor extension services make it difficult for transmission of new technologies and techniques of production to farmers. Thus, extension agents are important in facilitating farmer access to agricultural information.

Although agricultural extension was preferred there was a need for many channels and formats, which suggests that a combination of many formats and channels can lead to more understanding and uptake. The extension workers distributed posters and showed some short video clips when visiting farmers during the campaigns. Short messages were also share with farmers who had phones. About $90 \%$ of the farmers were exposed to print materials, while $60 \%$ and $15 \%$ were exposed to radio and video respectively. The farmers who were exposed to multimedia reported preference for information dissemination using the multimedia. This underscores the importance of multimedia in improving farmer knowledge. Other studies have also shown that a combination of videos, print materials, demonstrations and face-to-face interactions can deliver information better and facilitate uptake (Sharma 2016). In a study conducted in Pakistan, Shahid et. al. (2007) established that the most used form of print media for agricultural information was pamphlets followed by posters, newspapers, book/booklets, magazines and journals.

Table 3: Sources of information and preferred sources $(\%)$

\begin{tabular}{lcc}
\hline Sources of information & Source of information used & Preferred information source \\
\hline Visit by extension worker & 69.6 & 99.6 \\
Parents or guardian & 42.6 & 0.0 \\
Friends & 15.6 & 0.0 \\
Printed materials e.g. poster & 11.8 & 64.0 \\
Radio & 9.5 & 58.9 \\
Cooperative or village meeting & 8.8 & 0.0 \\
Trader or processor & 4.6 & 0.0 \\
Mobile phones & 10.0 & 43.0 \\
Videos & 5.0 & 47.2 \\
\hline
\end{tabular}

There were significant differences $(\mathrm{p}<0.01)$ in farmer perceptions of what is used and preferred with respect to three main sources of information. According to McNemar test there is a significantly high preference for extension workers $\left(\chi^{2}=66.02, \mathrm{p}<0.01\right)$. Based on a binomial distribution there was also a significantly high preference for radio $(\mathrm{p}<0.01)$ and printed materials such as posters $(\mathrm{p}<0.01)$. There is also high preference for videos, which were used in the campaigns to support the printed materials. Expanding use of videos may be a worthwhile consideration.

Most extension officers (97.8\%) subscribe to the farmers' views that they are the most effective source of information for the farmers. According to extension officers the farmers' main source of information was posters that they distributed during visits to the farmers' farms (Table 4). Materials provided by agro-dealers were also of critical importance to the farmers. Agro-dealers also distributed posters and flip charts to the farmers. Radios were also important sources of information for the farmers. These findings suggest that a combination of posters, farmers' training, flip charts, videos and radio provided a good distribution mechanism for the messages to the farmers. 
Table 4: Information sources for farmers according to extension officers (\%)

\begin{tabular}{lc}
\hline Information source & Extension officers (\%) \\
\hline Extension workers distributing posters & 97.8 \\
Agro-dealers explaining through a flip chart & 50.0 \\
Radio & 41.3 \\
Short video through phones & 26.1 \\
Video in viewing centres & 8.7 \\
\hline
\end{tabular}

Assessment of different sources of information for specific practices and inputs revealed that the extension officers were the overall leaders in delivering information. Table 5 shows the percentage of farmers that received information from the listed sources.

Table 5: Relative importance of sources of information for specific inputs and practices (\%)

\begin{tabular}{|c|c|c|c|c|c|c|}
\hline Source of information & $\begin{array}{l}\text { Impro } \\
\text { ved } \\
\text { seed }\end{array}$ & $\begin{array}{l}\text { Inoc } \\
\text { ulan } \\
\text { t }\end{array}$ & $\begin{array}{l}\text { Fert } \\
\text { ilize } \\
\mathbf{r} \\
\end{array}$ & $\begin{array}{l}\text { Planting in lines } \\
\& \\
\text { spacing }\end{array}$ & $\begin{array}{l}\text { Harvestin } \\
\text { g by } \\
\text { cutting }\end{array}$ & $\begin{array}{l}\text { Selling } \\
\text { to } \\
\text { market }\end{array}$ \\
\hline $\begin{array}{l}\text { Agricultural Development Program } \\
\text { (ADP) }\end{array}$ & 5.4 & 0.5 & 2.7 & 0 & 0 & 0 \\
\hline Agro-dealer & 9.2 & 15.2 & 9.7 & 0 & 0 & 3.2 \\
\hline Extension worker & 47.8 & 57.8 & 37.4 & 68.6 & 69.8 & 15.6 \\
\hline Niger $\quad$ Agricultural & & & & & & \\
\hline $\begin{array}{ll}\text { Mechanization } & \text { Development } \\
\text { Agency (NAMDA) } & \end{array}$ & 0.4 & 0 & 0.5 & 0 & 0 & 0 \\
\hline Local market & 2.1 & 0.5 & 18.4 & 0 & 0 & 25 \\
\hline Friends & 2.1 & 0.5 & 0.5 & 2.2 & 3.1 & 0 \\
\hline $\begin{array}{l}\text { Kaduna Agricultural Development } \\
\text { Agency (KADP) }\end{array}$ & 6.8 & 7.3 & 6.5 & 7 & 5.9 & 0 \\
\hline Farmers & 2.1 & 0 & 0 & 1.2 & 0.6 & 0 \\
\hline $\begin{array}{l}\text { International Fertilizer Development } \\
\text { Centre (IFDC) }\end{array}$ & 0.4 & 0 & 0 & 0 & 0 & 0 \\
\hline $\begin{array}{l}\text { Institute of Agricultural Research } \\
\text { (IAR) }\end{array}$ & 0.4 & 0 & 0 & 0 & 0 & 0 \\
\hline United States Agency for & & & & & & \\
\hline $\begin{array}{l}\text { International Development (USAID } \\
\text { II) }\end{array}$ & 5.4 & 5.7 & 0 & 5.9 & 5.9 & 0 \\
\hline $\begin{array}{l}\text { International Institute of Tropical } \\
\text { Agriculture (IITA) }\end{array}$ & 6.7 & 7.3 & 5.9 & 5.4 & 4.8 & 0 \\
\hline $\begin{array}{l}\text { Borno State Agricultural } \\
\text { Development Program (BOSADP) }\end{array}$ & 7.5 & 0 & 6.5 & 6.5 & 5.9 & 0 \\
\hline N2AFRICA & 3.3 & 4.7 & 2.2 & 1.6 & 1.2 & 0 \\
\hline NOTORE Fertilizer Company & 0 & 0 & 0.5 & 0 & 0 & 0 \\
\hline Open market & 0 & 0 & 7.6 & 0 & 0 & 0 \\
\hline Anchor borrower programme & 0 & 0 & 0.5 & 0 & 0 & 0 \\
\hline Parents & 0 & 0 & 0 & 1.1 & 0.6 & 0 \\
\hline Training & 0 & 0 & 0 & 0.5 & 1.6 & 0 \\
\hline Self-initiative & 0 & 0 & 0 & 0 & 0.6 & 0 \\
\hline Research & 0 & 0 & 0 & 0 & 0 & 15.6 \\
\hline HULE and Sons Company & 0 & 0 & 0 & 0 & 0 & 40.6 \\
\hline
\end{tabular}

3.3 Language preferred by farmers for information dissemination

Farmers in different regions preferred certain languages for delivery of information. In particular, the local languages spoken in the areas were the ones preferred by farmers. Historical pointers revealed that some farmers that had not passed through formal education are still be able to read local languages due to training from religious establishments. Consequently, information packaging and dissemination efforts need to consider language preferences by farmers. Mokotjo and Kalusopa (2010) revealed that, though most of the farmers in their study in Lesotho had acquired primary education, the agricultural information delivered to them was written in local languages. This enabled farmers to utilize the information effectively. This suggests that even if some radio channels are in general predominant in particular areas farmers would prefer FM stations that broadcast in particular local languages. 


\subsection{Utilization of the campaign messages by the farmers}

Farmers were aware of many practices in soybean production. Some of the practices had been learned from their fore fathers and other farmers while some practices had been learned from the agricultural extension officers as well as the campaigns. Information/practices that farmers were aware of, had interest in and used before the campaigns were the use of improved seeds and planting in lines with correct spacing (Table 6). Application of fertilizers was also one of the practices that farmers were aware of and used.

Table 6: Information that farmers were aware of and information used after campaigns

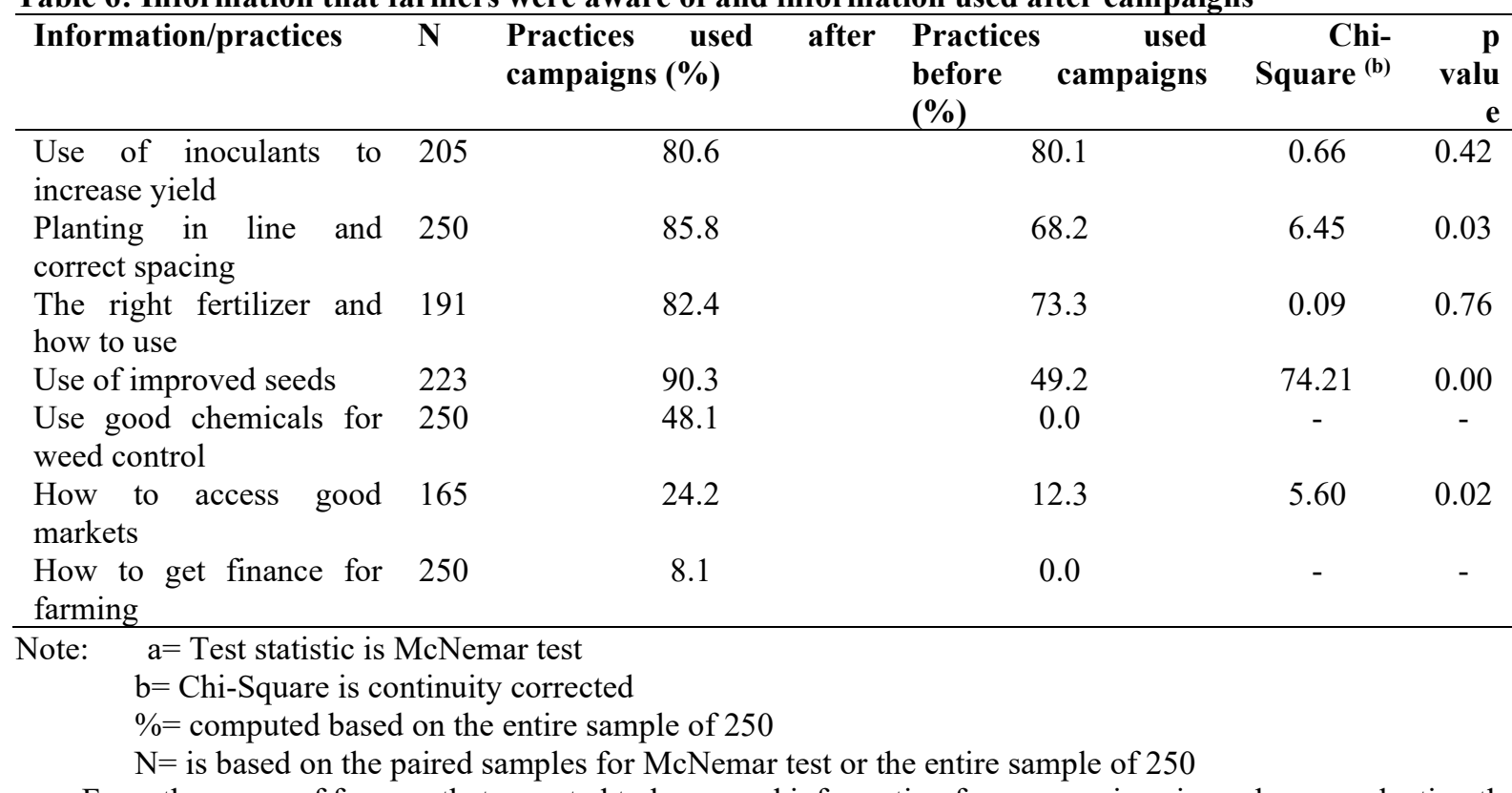

From the group of farmers that reported to have used information from campaigns in soybean production the extent of use of the different practices varied. The practice that was widely used following the campaigns was how to use inoculant to increase yield. This was followed by line planting and correct spacing, selection and use of fertilizers and then selection and use of improved seeds/varieties (Table 6). Thus, farmers require a basket of options and efforts to address predicaments to facilitate movement to higher levels in the soybean value chain.

There were significant differences in application of practices before and after receipt of the campaign messages with respect to use of improved seeds $(p<0.01)$ and how to access markets $(p<0.05)$ for selling soybean. Receipt of campaign messages contributed to use of more practices by farmers. The variation between what the farmers knew and what they practised can also be attributed to farmer capacity to apply the messages. The extent of use of the inoculants was not different from what was known before the campaigns possibly because those who knew were the same ones that had the capacity to use after receipt of the messages from the campaigns.

Most of the farmers $(66 \%)$ used the information that they received from the campaign messages. Only $34 \%$ of the farmers never used the information. The extent of information use demonstrates that multimedia campaigns were instrumental in encouraging farmers to use the practices. Hence the use of multimedia campaigns to promote agriculture technologies is warranted.

A binary logistic regression was performed to model the relationship between the predictors and application/no application of the practices. In this case the dependent variable was dichotomous where 1 represented application (use) of all the practices and 0 represented no application of the practices. The independent variables are measured on a scale of 1 or 0 except age and size of soybean farm. The traditional 0.05 criterion of statistical significance was employed for all tests. Addition of the predictors to a model that contained only the intercept significantly improved the fit between model and data, chi-square $(\mathrm{df}=34, \mathrm{~N}=173)=67.562$, Nagelkerke $\mathrm{R}^{2}=0.449, \mathrm{p}<.00$. Table 7 provides results for only the variables that were statistically significant. 
Table 7: Results of binary logistic regression model

\begin{tabular}{lrrrrrr}
\hline Description of variables & B & Std. Error & Wald & df & Sig & Exp(B) \\
\hline Age (years) & -2.151 & 0.988 & 4.744 & 1 & 0.029 & 0.116 \\
Gender (male or female) & 1.135 & 0.571 & 3.951 & 1 & 0.047 & 3.113 \\
Size of your soybean farm (acres) & 2.796 & 1.452 & 3.708 & 1 & 0.054 & 16.372 \\
Receipt of information on planting \& correct spacing & 1.160 & 0.533 & 4.741 & 1 & 0.029 & 3.191 \\
Message being clear and easy to use & 1.467 & 0.536 & 7.498 & 1 & 0.006 & 4.338 \\
Use of the practice prior to campaigns & 1.497 & 0.768 & 3.801 & 1 & 0.051 & 4.467 \\
Inputs being cheap & -4.020 & 1.583 & 6.452 & 1 & 0.011 & 0.018 \\
Receipt of information on benefits of the practice & -1.172 & 0.586 & 3.993 & 1 & 0.046 & 0.310 \\
Inputs provided free & -1.865 & 0.835 & 4.991 & 1 & 0.025 & 0.155 \\
\hline
\end{tabular}

Factors that significantly influenced use of the practices were receipt of information on line planting and correct spacing, clarity of information and farmer capacity as demonstrated by whether farmers would receive inputs free. Benefits expected from use of the practices and the exposure to (use of) practices prior to the campaigns were also important in influencing application of the practices. These show that information from multi-media campaigns was useful and complemented information from other sources. Information on line planting and correct spacing was critical in influencing use of the other practices possibly because of the farmers' appreciation of correct plant population in increasing yield and optimising input use.

\subsection{Factors that motivated farmers to use the messages}

Farmers reported many factors that motivated them to use the practices/messages. Key factors were the message being very clear and easy to practice, benefits of the practice and previous use of the practice (Table 8 ). These findings suggest that the format in which the messages are delivered to the farmers is a critical factor in determining use of the information provided. Costs and benefits need to be explicit and at the same time expectations on gross margin or cost-benefit analysis scenarios should be provided. In addition, Celine and Tsue (2013), established that with moderate profitability of soybean enterprise, farmers would be encouraged to cultivate the crop not only for insurance against food insecurity but also for monetary gains. Arguably, a comparison of traditional methods and the new methods is critical to demonstrate gains that would facilitate uptake of new methods. These indicate that information on expected benefits/ key attributes of the technologies to which the messages relate need to be provided to the farmers. Sanginga et al (1999) affirms that farmers' assessment of the attributes of improved varieties were important in explaining their adoption behaviour.

Table 8: Factors that motivated farmers to use the practices/messages (\%)

\begin{tabular}{lcc}
\hline Motivating factors & All messages & Messages on nodumax \\
\hline Message clear and easy to practice & 69.2 & 68.9 \\
Benefits of using the practice & 69.5 & 59.1 \\
Use of the practice before the campaigns & 19.7 & 19.0 \\
Inputs were easily available & 18.3 & 24.0 \\
Inputs were provided for free & 11.3 & 4.5 \\
Inputs were cheap & 4.2 & 4.5 \\
Inputs were provided on credit & 2.8 & 0.0 \\
\hline
\end{tabular}

Further analysis to establish what motivated farmers to use the practices was done using noduMax, which is a special input in soybean production. It emerged that clarity of the message and ease of use was an important factor. The second most important factor that motivated farmers to use nodumax was the benefits associated with its use. Although it is the case that farmers would involve themselves in many practices for soybean production; they appreciated practices that would lead to improved incomes from the campaigns.

According to the extension officers (55\%), farmers need to prioritize use of noduMax and its application. This should be followed by the use of improved seeds according to $21 \%$ of the extension officers. Improved soybean varieties have higher yield that justify investment (Ogunsumi et al, 2007). Use of chemicals to control weeds and correct plant spacing are important as reported by $6 \%$ of the extension officers respectively. Overall, $62 \%$ of the extension officers had the view that the key factor to motivate farmers to use the messages is the need to increase soil fertility and yield. This was followed by the approach being good and easy to apply as reported by $13 \%$ of the extension officers. Thirteen percent of the extension officers reported that encouragement of the farmers through training also motivated them.

The farmers' perception and extension officers' views indicate that messages provided to encourage use of certain practices should be accompanied by the information on expected gains/benefits and comparisons with existing practices. Farmers also need to be provided with messages on expected costs and how to access inputs.

3.6 Benefits of the campaign messages to the farmers, extension officers and agro-dealers

Thirty six percent of the farmers reported that the practices/messages enabled them to get increases in soybean 
output. Assessment of production over the previous three years showed that there was a high increase during the campaign year (2017), especially for the farmers that produced relatively large quantities of soybean (Table 9). In the lower production levels $(50-2000 \mathrm{~kg})$ there was a noticeable decline in numbers of farmers who were only achieving these lower yields.

\begin{tabular}{lccc} 
Table 9: Percentage of farmers reporting different production levels & $\mathbf{( 2 0 1 5 - 2 0 1 7 )}$ \\
\hline Production category (kg) & $\mathbf{2 0 1 5}$ & $\mathbf{2 0 1 6}$ & $\mathbf{2 0 1 7}$ \\
\hline $50-2000$ & 85.2 & 87.6 & 81.1 \\
$2001-4000$ & 11.4 & 7.4 & 12.0 \\
$4001-6000$ & 1.3 & 2.7 & 3.0 \\
Over 6000 & 2.1 & 2.3 & 3.9 \\
\hline
\end{tabular}

Discussions with farmers revealed that receipt of information from multimedia campaigns; involving radio, print and videos were very instrumental in increasing soybean production. All types of information provided by multimedia campaigns contributed to increasing soybean production.

Discussions with extension officers and agro-dealers revealed that most of them had learned something new from the campaigns. Hence, extension officers need to be equipped with extension tools and support materials, which further enhances dissemination and learning. The major new information was on the use of the noduMax inoculant (Table 10). Exposure of extension officers to the practices was a refresher course and a learning experience for others. This was meant to increase knowledge of extension officers participating in dissemination efforts. Likewise, Agada (2015) reported that there is need for training and re-training of extension workers to effectively disseminate soybean improved technologies to farmers. The agro-dealers learnt more new information on use of SSP fertilizer compared to extension officers. Findings here align with submissions by David and Cofini, (2017) that facilitators or advisors with good technical knowledge and facilitation skills are a common factor that contribute to success in implementing advisory methods.

Table 10: New information learned by extension officers and agro-dealers (\%)

\begin{tabular}{lcc}
\hline Type of information & Extension officers & Agro-dealers \\
\hline Use of inoculant & 59.5 & 52.8 \\
Use of improved seeds & 13.5 & 13.9 \\
Planting in lines \& correct spacing & 8.1 & 8.3 \\
Cutting stem during harvesting & 8.1 & 8.3 \\
Use of SSP fertilizer & 8.1 & 16.7 \\
\hline
\end{tabular}

About $21.6 \%$ of the agro-dealers reported that the campaigns increased sales while $8.1 \%$ reported that the campaigns created business recognition. Another group of $27 \%$ argued that campaigns encouraged more production of soybeans. The campaigns also promoted market for soybeans as reported by $43.2 \%$ of the agrodealers. All the reported effects were useful to the agro-dealers in terms of increasing direct sales of the inputs or contributing to increases in sales due to prospects for increasing production of soybeans. About $40 \%$ of the agrodealers reported that they had been selling noduMax before the campaigns. After the campaigns $37.5 \%$ of the agrodealers that had been selling noduMax reported that they had realized increase in noduMax volumes sold in the season after the campaigns.

\subsection{Challenges to the use of campaign messages}

The challenges/difficulties that farmers encountered regarding the use of information from the campaigns included mainly the fact that the inputs were expensive (Table 11). This means that farmers require support to access finances to adopt recommended soybean production practices. This was corroborated by the farmers reporting that the inputs not being provided on credit was also one of the challenges. Extension officers also noted that lack of access to funds for use in farming was a major hindrance to the application of new farming practices. Agada (2014) suggests that farmers should be facilitated to access credit for the purchase of vital inputs for increased soybean production and productivity. This supports the view that campaigns aimed at improving soybean production should also provide information that would facilitate farmers' access to credit or funds for investment in soybeans. This could be through group action or group collateral or farm produce. According to Ifeanyi et. al. (2007) interactions among farmers during meetings of co-operatives and other non-formal associations are good networks for promoting farmer-to-farmer dissemination of information and circulation of technologies.

Farmers also reported that inputs were not readily available and as a consequence it was difficult to use the messages. Special inputs such as inoculants were checked and farmers noted issues of poor availability of the said inputs. Farmers also noted that they were not able to get the inoculants because they were costly or not available in the local areas or the distance to the selling points was long. Sixty-six percent of the farmers reported that noduMax was not readily available in the community if they needed to buy it. This means that campaigns that promote the use of particular inputs and practices should provide information that can increase access to inputs for the farmers to purchase. Those running the campaigns also need to engage with local suppliers to encourage stocking of the required inputs. Generally, the adoption of many improved packages of technology can be 
compromised by the lack of availability of other complementary farm inputs. Availability of seeds and other crucial inputs are very vital if the speed of adoption of the technology is to be improved (Zoundji et. al., 2015). Mutegi and Zingore (2017) add that achieving high soybean yields in Sub Saharan Africa will require supporting farmers by improving availability of inputs (fertilizer and seeds), input financing and access to remunerative output markets. It is also necessary for improved inputs to be made available on time, in right amounts and at affordable prices to the farmers by the government and other stakeholders in order to enhance production (Girei et. al., 2018). This can be facilitated by the extension agents linking farmers to agro-input dealers to enable them purchase vital inputs at the right time and at reasonable prices (Agada, 2015). In this regard providing information regarding source of inputs especially agro-dealers and their locations is necessary.

Table 11: Challenges to the application of the practices disseminated by campaigns (\%)

$\begin{array}{ll}\text { Challenges to the use of campaign messages } & \text { Farmers reporting }\end{array}$

$\begin{array}{lc}\text { The inputs were expensive } & 55.2 \\ \text { Inputs were not provided free } & 34.3 \\ \text { The inputs were not readily available to buy } & 25.9 \\ \text { Had not been using the practice before } & 14.7 \\ \text { Inputs were not provided on credit } & 14.0 \\ \text { Benefits of the practice were not clear } & 7.0 \\ \text { Message was not very clear and easy to practice } & 3.5\end{array}$

Limited appreciation of the expected benefits of using messages also made it difficult for the farmers to use the information in the messages. Farmers are rational in their actions and would naturally refuse to use the information if the benefits are not explicit. Farmers usually choose and use technologies that are within their technical and economic capacities (Ugbabe, 2017). Messages and information should be disseminated in such a manner that the farmers will understand the message and information being communicated. Providing solutions for difficulties encountered can enable farmers to use the information in the messages and be able to achieve higher levels of efficiency that would lead to increased yields and hence higher revenue generation and higher profits.

Messages not being clear and easy to use was also another challenge although it was reported by a very small percentage of farmers. Making information clear and in format that can be easily understood is key to success in using messages.

The difficulties encountered with respect to use of the messages are in line with those found by other studies. For instance, Umaru (2015) established that the most important constraints faced by farmers to the adoption of recommended soybean production practices were high cost of the technology, insufficient credit facilities, inadequate awareness and complexity of the technology.

\subsection{Challenges in delivery of messages}

Extension officers and agro-dealers received different types of materials to distribute to the farmers. Levels of distribution varied with the type of material that was involved (Table 12).

Table 12: Campaign materials received/ distributed by extension officers \& agro-dealers (\%)

\begin{tabular}{llllll}
\hline $\begin{array}{l}\text { Types of materials received and } \\
\text { distributed }\end{array}$ & $\begin{array}{l}\text { Received } \\
\text { (extension } \\
\text { officers) }\end{array}$ & $\begin{array}{l}\text { Distributed } \\
\text { (extension } \\
\text { officers) }\end{array}$ & $\begin{array}{l}\text { Received } \\
\text { (agro- } \\
\text { dealers) }\end{array}$ & $\begin{array}{l}\text { Distributed } \\
\text { (agro- } \\
\text { dealers) }\end{array}$ \\
\hline Posters on how to use inoculant & 90.9 & 90.9 & 72.5 & 69.4 \\
Flip chart on how to grow soybean & 75.0 & 61.4 & 62.5 & 50.0 \\
Videos on phone on how to grow soybean & 44.4 & 27.3 & 17.5 & 13.9 \\
Videos on phone on how to use inoculant & 42.2 & 20.5 & 17.5 & 16.7 \\
Radio messages on how to grow soybean & 20.0 & 13.6 & 17.1 & 15.4 \\
\hline
\end{tabular}

Extension officers and agro-dealers had challenges while distributing campaign messages. These challenges compounded farmers' challenges regarding use of the messages. The main challenge encountered by extension officers was that most farmers were far from the working station of the extension officers (Table 13). Extension officers also reported that most farmers did not have phones to receive videos. 


\section{Table 13: Challenges faced by extension officers and agro-dealers in delivering messages (\%)}

\begin{tabular}{lcc} 
Challenges & Extension officers & Agro-dealers \\
\hline Farmers were located too far away & 59.5 & 0 \\
Farmers did not have phones to receive the video & 45.2 & 21.2 \\
Did not have the network to share the video & 35.7 & 36.4 \\
Lack of money for transport to the farmers & 33.3 & 42.4 \\
No free time & 14.3 & 27.3 \\
Farmers were not interested in the materials & 7.1 & 9.1 \\
Farmers were not coming to receive the information & 4.8 & 12.1 \\
Farmers did not have radio to listen to the messages & 4.8 & 3 \\
Did not fully understand how to use the materials & 2.4 & 100
\end{tabular}

Agro-dealers reported that the main challenge in delivering information to the farmers was the fact that they did not fully understand how to use the materials. Failure to disseminate materials was also attributed to the fact that some farmers had no phones to receive messages and videos (Table 15). More than half of the agro-dealers $(52.3 \%)$ did not stock all the inputs promoted through the campaigns, such as noduMax. This suggests that when a campaign is run it is necessary to engage with the agro-dealers to make sure they have the products in stock. It may also be good to work with them during the campaign preparation phase.

\subsection{Lessons learnt for future campaigns}

Farmers that used the messages disseminated demonstrated change in production practices and increased soybean production. Farmers also expressed the need to be linked to markets and marketing agencies to ensure access to production inputs (such as noduMax) and efficient marketing of their produce, which would lead to the desired end of improved livelihoods. This is consistent with a study by Celine and Tsue (2013) which recommended that government should create enabling environment for marketing of soybean, which should include provision of market infrastructure such as good rural access roads and good storage facilities, to enable the farmers sell at the time they want and at a good price. Ugwu and Ugwu (2010) argue that the marketing system should be developed for soybean products to encourage large scale domestic and export of soybean products in Nigeria. Storage of noduMax is difficult for the farmers and it must be easily accessible for the farmers to buy small quantities that they can use quickly and over a short period of time. Improving efficiency of the input markets is critical.

Information/messages disseminated through multiple sources and formats are more easily understood and used by farmers. Apart from the conventional source of agricultural information to the farmers, extension officers, farmers prefer to use other sources of information especially the radio, videos and mobile phones. Messages could also be disseminated in different languages but the focus should be on common/local languages. Benefits associated with the use of the different technologies should be shown to the farmers to help facilitate adoption/ use of the information.

Messages and information aimed at improving soybean production should also include information on how to access funds for use to purchase inputs and for other agricultural practices on the farm. This is corroborated by Celine and Tsue (2013) who identified major constraints in soybean production as inadequate capital, soil infertility, poor extension services, high cost of inputs, inadequate, marketing/storage facilities and high cost of transportation. Information on funds should include sources of credit, collateral requirements and how farmers can effectively utilize the funds. Sources of credit especially banking financial institutions require production records. As a consequence, farmers should be encouraged to keep farm records.

The interrelationship between information provided and that required by the farmers indicates that farmers should be provided with adequate information to help build their capacities and competence in soybean production. Where necessary formative appraisal should be conducted before campaigns in order to provide required information.

The inoculant (noduMax) was not available in most of the agro-dealer shops. Discussions with agro-dealers revealed that it was very difficult to store and it had a short shelf life. This suggests the need for measures on how to increase the shelf life of noduMax. Policy initiatives to redirect research in this direction would help improve the use of noduMax for improved soybean productivity. Some agro-dealers did not understand how to use the information. Consequently, agro-dealer's seminars would be necessary to help them understand the information for effective delivery. Extension officers reported limited access to farmers given that some farmers were located far and could not be reached easily. In this case, use of phones to disseminate information could be considered, since farmers indicated phones as one of the preferred sources of information.

\subsection{Conclusion}

This study presents evidence that the soybean campaign delivered benefits to farmers who participated. Farmers learned and practiced productivity enhancing technologies in particular selection of the right varieties, correct spacing, use of inoculants and application of fertilizers. This translated into increased soybean productivity during 
the campaign season.

Using multimedia campaigns particularly, allowed farmers to interact with messages in various formats adding benefits to learning and knowledge retention. Farmers however, indicated preference for extension workers as their information source. This may be based on trust they have in extension agents, or simply due to interactivity that this approach offers. This suggests the need to improve interaction by incorporating feedback mechanisms in radio programming, integrating a listening group strategy to enhance peer learning among target farmers, and other approaches that promote participation. Integrating these approaches would help address the current extension challenges of farmer reach occasioned by logistical challenges and accessibility due to long distances to the farmers' location.

Campaign messages are likely to have the greatest reach using print materials for interpersonal engagement of farmers by the extension workers across all target states and the deployment of light format short videos for young farmers in some states. Routing the campaign through existing extension partners of N2Africa as well as using the campaign as a tool for preparing the target farmers for participation in the Anchor Borrower Program also significantly helped the response of farmers to the campaign.

Farmers demonstrated capacity to apply messages that had clear benefits. To facilitate uptake and use of messages they should be accompanied by indications of benefits and where possible rated against common/existing farmer practices. Using multi-media effectively contributes to and complements other methods of disseminating soybean production information.

The information provided on production practices should be associated with information to facilitate access to funds to help the application of recommended practices. The diversity of information required demands that farmers be given access to many options from which they can make decisions based on their capacity. Of all the elements of the campaign, the print materials were the ones with the farthest reach followed by the radio. The preferred print material was the poster explaining the practices.

Extension officers should be supported by other methods. A key solution in this regard is use of the radio and agro-dealers. It is therefore necessary to select appropriate radio channels per target group. In this regard language consideration is of special importance as well as the time messages are aired and in particular production stage specific messages. Due regard should be given to local languages in radio broadcasts and print materials. Agrodealers and some farmers noted that they did not fully understand some messages. Consequently, messages should be easy to understand by farmers and agro-dealers. Repackaging posters and flipchart in simpler forms targeting specific stages in the soybean calendar is warranted. Formats in which messages are delivered also have to consider capacity of the farmers. In some instances, extension officers could not deliver specific messages because farmers had no phones with capacity to use videos. However, given farmer preference for phones as one of the sources for information it would be necessary to explore options for diversified use of phones such as WhatsApp groups and sharing of phone messages by lead farmers, friends or family members.

\section{Acknowledgments}

This paper is produced as part of the activities of the ASHC Programme which is supported by Bill and Melinda Gates Foundation. CABI is an international intergovernmental organisation and we gratefully acknowledge the core financial support from our member countries (and lead agencies) including the United Kingdom (Department for International Development), China (Chinese Ministry of Agriculture), Australia (Australian Centre for International Agricultural Research), Canada (Agriculture and Agri-Food Canada), Netherlands (DirectorateGeneral for International Cooperation), and Switzerland (Swiss Agency for Development and Cooperation). See https://www.cabi.org/about-cabi/who-we-work-with/key-donors/ for details

\section{References}

Ado Makama Adamu, Abdul Amina Haruna and Mangadu Mohammed Maigari. (2016), Entrepreneurial Features of Soybean a Gateway to Self-Employment Opportunity and Poverty Reduction in Nigeria. IOSR Journal of Business and Management, 18(12): 13-17

Agada M.O. 2015, Constraints to Increasing Soybean Production and Productivity in Benue State, Nigeria. Asian Journal of Agricultural Extension, Economics and Sociology 4(4): 277-284

Agada. M.O. (2014), Technological Capabilities among Soybean Producers in Benue State, Nigeria. Journal of Biology, Agriculture and Healthcare, 4(10): 104-113

Asaju, K, S. Arome and S. Anyio. (2014. The rising rate of unemployment in Nigeria: The Socio-economic and political implications, Global Business and Economic Research Journal,3(2): 12-32. Available online at http://www.journal.globejournal.org

Asogwa, B. C., Ezihe, J. A. C., and Ogebe, F.O. (2012), Agricultural Marketing Information Usage among Soybean Farmers in Nigeria. International Journal of Innovation and Applied Studies, 1(2): 160-170.

Celine K. Biam and Tsue T.P. (2013), Profitability of Soybean Production by Small Holder Farmers in Nigeria: A Guide for Sustainable Food Security. European Journal of Business and Management. 5(30): 69-97. 
David, S. and Cofini, F. (2017), A decision guide for rural advisory methods. Rome: Food and Agriculture Organization of the United Nations.

Dugje I.Y., Omoigui L.O., Ekeleme F., Bandyopadhyay R., Lava Kumar P., and. Kamara A.Y. (2009), Farmers' Guide to Soybean Production in Northern Nigeria. International Institute of Tropical Agriculture, Ibadan, Nigeria. $21 \mathrm{p}$.

Egwu, Emeka Williams. (2014), Assessment of constraints in dissemination of agricultural Biotechnology in Ebonyi North Agricultural Zone, Ebonyi State, Nigeria. Research Journal in Engineering and Applied Sciences 3(1) 73-80

Girei, A. A., Ohen, S. B and Filli, F. B. (2018), Econometrics analysis of soybean production in Doma Local Government Area of Nasarawa State, Nigeria. Journal of Agricultural Science and Practice, 3(4): 90-96.

Mutegi James and Zingore Shamie. (2017), Boosting soybean production for improved food security and incomes in Africa. IPNI, Sub-Saharan Africa Program. http://ssa.ipni.net/

Ifeanyi A.O., Manyong V.M. and Ikpi A.E. (2007), Determinants of rural farmers' improved soybean adoption decisions in northern Nigeria. Journal of Food, Agriculture and Environment 5 (2): 215-223

LawalIro S.; Boadi, B.Y.; Oladokun, O.; Kalusopa, T. (2014), The Generation and Dissemination of Agricultural Information to Farmers in Nigeria: A Review. IOSR Journal of Agriculture and Veterinary Science (IOSRJAVS) 7(2): 102-111.

Mbah B. N., Uwaegbute K.C., Enwere N. J. and Onah N.B. (1992), The status of soybean production, processing and utilization in Okutu, Ozalla and Enugu in Enugu state, Nigeria. Ibadan: International Institute of Tropical Agriculture, 20p.

Michael David. (2011), Soybeans and products. Lagos: Global agricultural information network report.

Mokotjo, W. and Kalusopa, T. (2010), Evaluation of the agricultural information service (AIS) in Lesotho. International Journal of Information Management, 30, 350-356.

Ogunsumi L.O., Adegbite A.A. and Oyekan P.O. (2007), Economic Impact Assessment for Technology: The Case of Improved Soybean Varieties in Southwest Nigeria. Journal of Agriculture and Rural Development in the Tropics and Subtropics, 108(1): 79-86.

Ojiako F.A., Manyong V.M. and Ikpi A.E. (2010), Economic analysis of soybean farming in Northern Nigeria. Nigeria Agricultural Journal 41(1): 1-9. https:/www.ajol.info/index.php/naj/article/view/90558

Olomola A.S. (2007), Competitive Commercial Agriculture in Africa: Nigerian Case Study. Ibadan: Nigerian Institute of Social and Economic Research (NISER). 175p

Omotayo, A. M., Olowe V. I. O., Fabusoro E., Babajide J. M., Ojo D. K. and Adegbite D. A. (2007a), Making Nigerian Agricultural Markets Work for the Poor: Commercial Demand for Soybean in Nigeria. Agricultural Media Resources and Extension Centre (AMREC) Monograph Series No. 29

Omotayo A. M., Fabusoro E, Jaiyeola M. A. Adeniji I. A. and Oyedepo J. (2007b), Mapping of soybean production areas in Nigeria. Agricultural Media Resources and Extension Centre (AMRE). Monograph Series No. 28, $76 \mathrm{p}$.

Opara, U. N. (2008), Agricultural information sources used by farmers in Imo State, Nigeria Information Development, 24(4): 289-292.

Ozowa, V. N. (2008), Information needs of small-scale farmers in Africa: The Nigerian example. Quarterly Bulleting of the International Association of Agricultural Information Specialist, 40(1): 1-6.

Ragsdale Kathleen, Mary R. Read-Wahidi and Audrey Reid. (2017), ICT4AgD \& Soybean Farmers in Rural Ghana: Focus Group Discussion Results among Men and Women Smallholder Soybean Farmers in Ghana's Northern Region. USAID and the Feed the Future Soybean Innovation Lab. Social Science Research Center, Mississippi State University. doi: 10.13140/RG.2.2.13859.04646. Available at http://preview.tinyurl.com/y92qq8w8

RMRDC (Raw Material Research and Development Council). (2004), Report on survey of agro-raw materials in Nigeria: Soybean. Federal Ministry of Science and Technology, Abuja, Nigeria; 2004.

Sahel. (2017), Soybean: On becoming a highly coveted crop. Vol 16. Available, accessed 29/01/2019. http://sahelcp.com/wp-content/uploads/2017/10/Sahel-Capital-Newsletter-Volume-16.pdf

Sanginga P.C., Adesina A.A, Manyong V.M, Otite O. and Dashiell K.E (1999), Social impact of soybean in Nigeria's southern Guinea savanna. Ibadan: International Institute of Tropical Agriculture, 34p

Sehu H.E., Kwari J.D. and Bzugu P.M. (2007), An exploratory survey of soybean production as influenced by soil nutrient status in Northeastern Nigeria. Journal of Agronomy 6(4): 576-580.

Shahid Farooq, Sher Muhammad, Khalid M Chauhdary and Ijaz Ashraf. (2007), Role of print media in the dissemination of agricultural information among farmers. Pakistan Journal of Agricultural Sciences 44(2): 12-19.

Sharma G.R.K. (2016), Effectiveness of Multimedia Modules on Dissemination of Knowledge among the Dairy Farmers. J Res Development 4: 142. doi:10.4172/2311-3278.1000142

Ugbabe O.O., Abdoulaye T., Kamara A.Y., Mbavai J. and Oyinbo O. (2017), Profitability and Technical 
Efficiency of Soybean Production in Northern Nigeria. TROPICULTURA 35(3): 203-214.

Ugwu D. S. and Nwoke U. M. (2011), Assessment of soybean products acceptability and consumption in Orumba South Local Government Area of Anambra State Nigeria. International Research Journal of Agricultural Science and Soil Science 1(8): 314-325.

Ugwu D.S. and Ugwu H.C. (2010), Soybean production, processing and marketing in Nigeria. J. of Appl. Sc. \& Dev. 1(1): 45-61

Umaru Ibrahim. (2015), Analysis of the adoption of recommended soybean production practices in Zaria Local Government area of Kaduna State, Nigeria. M.Sc. Dissertation, Ahmadu Bello University, Nigeria, 94p

Woomer, P.L., Baijukya, F. and Turner, A. (2012), Progress Towards Achieving the Vision of Success of N2Africa. www.N2Africa.org. $23 \mathrm{pp}$

Zoundji Charlotte Carmelle, Pascal Houngnandan, Houinsou Dedehouanou and Fatiou Toukourou. (2015), Determinants of soybean [Glycine Max (L.) Merrill] production system in Benin. Journal of Experimental Biology and Agricultural Sciences, 3(5): 431-439. 